\title{
Computation of cementation factor and saturation exponent for selected oil fields in southern Iraq
}

\author{
Amna M. Handhal ${ }^{*}$, Abdulhuseein N. Shnawa Al-Atabi**, Fadia Waleed Majeed ${ }^{*}$ \\ *Department of Geology, College of Science, University of Basrah, Basrah, Iraq \\ ${ }^{* *}$ South Oil Company, Basrah, Iraq
}

\section{$\underline{\text { Abstract }}$}

This study aims to calculate cementation factor and water saturation exponent for four different lithological formations from different oil fields in south of Iraq and compare the results with typical values of these reservoir parameters. The formations that being selected for this study are: Yamama Formation in West Quran (WQ-60 well), Zubair Formation in south Rumaila (Ru-64 well), Nahr Umr Formation in Luhais oil field (Lu-5 well), and Mishrif Formation in Tuba oil field (Tu-4 well). The cementation factor for clastic formations (Zubair and Nuhr Umr) was calculated via Wyllie (1949) and He (2005) empirical equations. It is found that the value of this parameter is estimated to be 1.1 and $1.90 \mathrm{~m}$ for the Zubair formation using Wyllie equation and is equal to 2.4 and $1.6 \mathrm{~m}$ for Nahr Umr Formation according to the He equation. For the carbonate formations (Yamama and Mishrif), the cementation factor was estimated using Borai (1987) and Focke and Munn (1987) equations. This parameter was equal to 1.3 for both formations according to Focke and Munn (1978) and estimated to be 1.95 and 1.98 for Yamama and Mishrif formations according to equation developed by the Borai. The calculated saturation exponent was 2.5, 2, 2.21 and 0.5 in Zubair, Nahr Umr, Mishrif, and Yamama formations, respectively. The new calculated values were then applied in the Archi equation to estimate water saturation. The obtained results were compared with that calculated in laboratory (from core). Results showed that Wyille equation is better than the He equation. The final result confirmed that Wyllie equation is more accurate than He equation for calculating cementation factor in sandstone, while Borai equation was more accurate than Focke and Munn equations for the cementation factor in limestone rocks. 


$$
\begin{aligned}
& \text { حساب معامل السمنتة واس التثبع لحقول نفطية مختارة في جنوب العراق } \\
& \text { آمنة مال الله حنظل، عبد الحسين نعمة العتابي، فادية وليد مجيد } \\
& \text { قسم علم الارض، كلبة العلوم، جامعة البصرة }
\end{aligned}
$$

الخلاصة

تم في هذه الدراسة حساب معامل السمنتة واس التشبع لاربعة تكاوين ذات صخارية مختلفة في حقول مختلفة

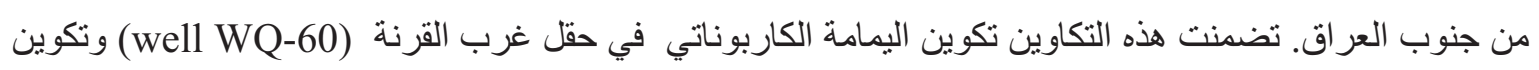
الزبير الرملي في حقل الرميلة الجنوبي (well Ru-64) و تكوين نهر عمر الرملي في حقل اللحبس (well Lu-5) وتكوين مشرف الجيري في حقل الطوبة (well Tu-4). حسب معامل السمنتة للنكاوين الرملية هما الزبير ونهر عمر فرين

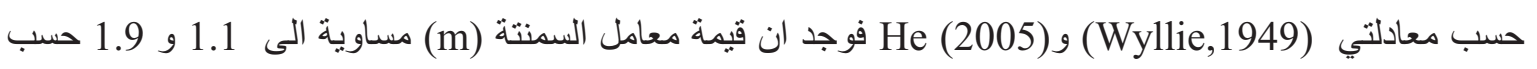
معادلة Wyllie لتكويني الزبير ونهر عمر على التوالي، ومساوية الى 2.4 و1.6 حسب معادلة He لتكويني الزبير

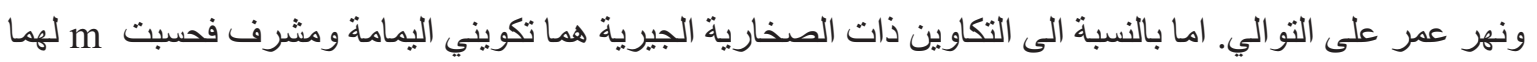
حسب معادلتي (Borai,1987) و (Focke and Munn, 1987)، فوجدت قيمة معامل السمنتة (m) مساوية الى فئل 1.3 حسب معادلة Focke and Munn , 1987 للتكوينين، ووجدت مساوية الى 1.95 و1.98 حسب معادلة Borai,1987 لتكويني اليمامة والمشرف على التو الي. وحسب اس التشبع (a) فوجدت قيمته مساوية الى 2.5 و 2 و 2.21 و 0.5 في تكاوين الزبير ونهر عمر ومشرف و اليمامة على التوالي. ثم طبقت القيم الجديدة في معادلة ارجي

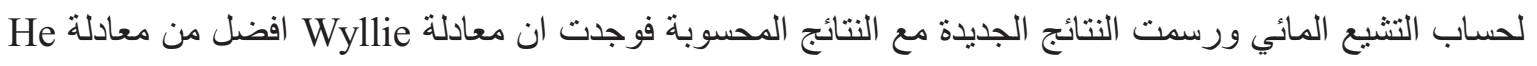

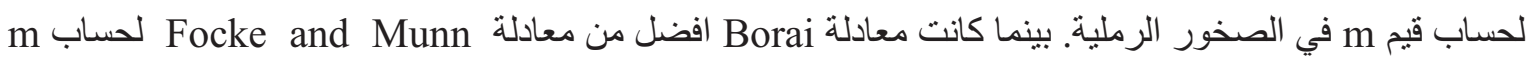

$$
\text { في الصخور الجيرية. }
$$

\section{Introduction}

Reservoir water saturation $\left(S_{w}\right)$ is an important factor for studying petroleum reservoir. Calculation of $S_{w}$ is an essential step for computing oil saturation and in place oil accumulation. The simplest way for calculating $S_{w}$ is Archie formula, which is defined mathematically as: $S_{w}=\left(\frac{a R_{w}}{\phi^{m} R_{t}}\right)^{\frac{1}{n}}$

where, $S_{w}$ is water saturation, $\phi$ is porosity (fraction), $R_{w}$ is formation water resistivity, $R_{t}$ is true resistivity of the formation, $a$ is tortuosity factor, $m$ is cementation factor, and $n$ is saturation exponent. $m$ is a measure of the degree of cementation and consolidation of the rock. As the degree of consolidation increase, the value of the cementation factor increase too [1]. The $m$ in Archie's equation plays an important role in the calculation of 
hydrocarbon and water saturation, which are indispensable parameters in the exploration of oil reservoir $[2,3,4]$. The poor estimates of the $m$ can cause errors in the calculation of the $S_{w}$ when using Archie's equation and may lead to discrepancies between log interpretation and production test results [5]. In petrophysics routine evaluation, Archie's parameters are held constants with default saturation exponent equals to 2 [4]. In fact, $n$ varies considerably from the default value of 2 in strongly water wet reservoir rocks to more than 20 in strongly oil wet reservoir rocks [6]. In addition, there are different factors affect on the $m$ parameter such as shape of the grain, geometry of the pore system, grain size, tortuosity, grain size distribution, porosity, influence of pore geometry and wettability.

In this study, Archie's parameters were computed using different formula and compare with those calculated with default values.

\section{Geological setting and stratigraphy}

The study area includes Four Formations in Four oil fields: Yamama Formation in West Qurna (well WQ-60), Zubair Formation in South Rumaila (well Ru-64), Nahr Umr Formation in Luhais oil field (well Lu-5) and Mishrif Formation in Tuba (well Tu-4) oil fields as shown in (Fig. 1). They are located south part of Iraq. According to the tectonic zones of Iraq, the study area is located within the Mesopotamian basin, in Zubair subzone according to the tectonic subdivision. The southern Rumaila third largest gathering in the world after oil fields in Kuwait (Burgan) and Ghawar in Saudi Arabia, this field was discovered in 1953. The field is located in the southern and southeastern Iraq, $50 \mathrm{~km}$ southwest of the city of Basrah, total area is about $520 \mathrm{~km}$. The West Qurna is one of Iraq's largest oil fields, located north of Rumaila field, west of Basra approximately $70 \mathrm{~km} \mathrm{NW}$ of Basra city. Tuba oilfield is located in Basrah, approximately $40 \mathrm{~km} \mathrm{SW}$ of Basrah city. Its coordinates are $30^{\circ} 28^{\prime} 60^{\prime \prime} \mathrm{N}$ and $47^{\circ} 4^{\prime} 60^{\prime \prime}$ E. Luhais oil fields is located in southern part of Iraq, $120 \mathrm{~km}$ west of Basrah, $60 \mathrm{~km}$ Southwest of North Rumaila oil. 


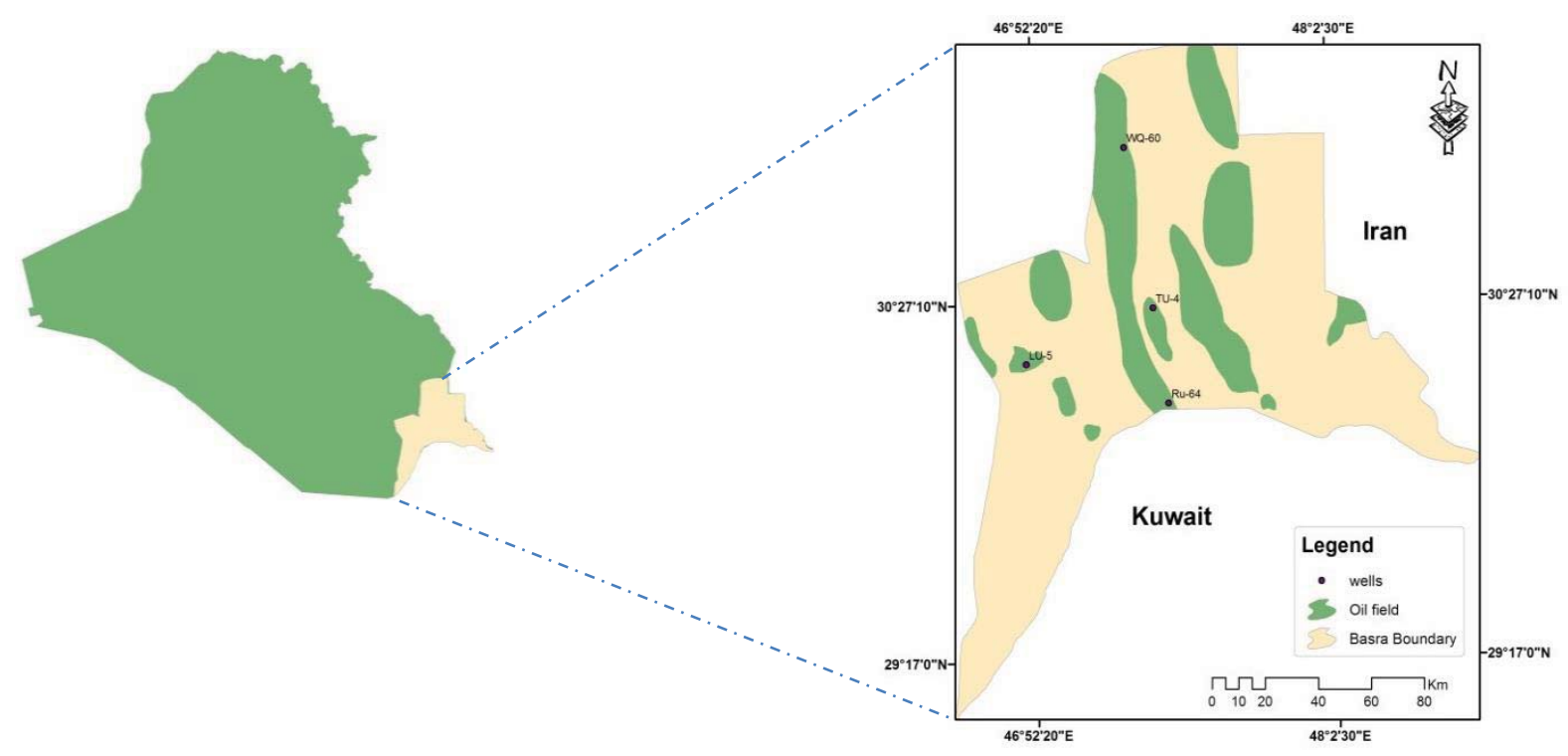

Fig. (1) The study area

The Yamama Formation in South Iraq comprises outer shelf argillaceous limestones and oolitic, pelloidal, pelletal and pseudo-oolitic shoal limestones [7]. Al Siddiki (1978) [8] has divided the Yammam Formation to five rocks units with different petrophysical properties, three of this units are reservoir (YA,YB,YC) separated by two units rocks (CI, CII) . The Yamama formation is of Berriasian- Valanginian age [9]. The formation is usually conformably overlain by the Ratawi Formation, towards the west cover the Salman zone, where the Yamama and Ratawi formations are absent, the Zubair Formation unconformably overlies Jurassic rocks [10]. The Zubair Formation is the most important formation of the Lower Cretaceous cycle in Iraq [11]. The formation comprises 380-400 $\mathrm{m}$ of alternating shale, siltstone and sandstone [7]. Owen and Nasser (1958) [12] divided the Zubair Formation into five members: Upper shale Member, Upper sand Member, Middle shale Member, Lower sand member and Lower shale member. The Zubair Formation is assumed to represent a prograding delta originating from the Arabian shield $[13,14]$. The age of the formation as determined based on fossils is Hauterivian till early Aptian [9]. While palynomrphs evidence extended this formation up to earliest Albian age [15].

The average thickness of this formation is $425 \mathrm{~m}$. The contacts of Zubair Formation are mostly gradational and conformable. The underlying formation is the Ratawi Formation 
which consists of dark, slightly pyretic shales interbedded with pseudo -Oolitic detrital limestone [9], and this is overlain by Shuaiba Formation which consists of dolometic limestone.The Nahr - Umr Formation is composed of sandstone and shale. It is defined by Glynn Jones in 1948 in [9] from the Nahr - Umr structure in south Iraq. It is up to $360 \mathrm{~m}$ thick in the south parts of the Salman and Mesopotamian zones [7]. At its type section in the Nahr - Umr field, it comprises black shales interbedded with medium to fine grained sandstone containing lignite, amber and pyrite [12]. The Nahr - Umr Formation is interpreted to be an alluvial to lower coastal plain to deltaic deposit with shallow - marine and aeolian influences [16, 17]. At Buzurgan, the formation includes glauconitic and bitumeinous sandstone and abmer [18].

Average TVD thickness of Nahr - Umr Formation is $260 \mathrm{~m}$, Nahr Umr Formation is an oil reservoir in some fields. The upper contact of the Nahr Umr Formation with the overlying Mauddud Formation is conformable and gradational, and is placed at the base of the limestone of the Mauddud Limestone Formation and the top of the black shale of the Nahr Umr Formation [19]. The lower contact of the Nahr Umr Formation at the type section is with the Shuaiba Limestone Formation, where a disconformity was established on regional evidence [20]. The Mishrif Formation represents a heterogeneous formation originally described as organic detrital limestone, with beds of algal, rudist, and coral-reef limestone, capped by limonitic fresh water limestone [9].

Mishrif Formation is divided into two main reservoir units: upper Misherif and lower Misherif Separated by unit of shale. The Cenomanian-early Turonian is the Mishrif Formation age. The formation thins towards the West and NorthWest, while its thickness in the Rumaila and Zubair fields reach 270 m, in the Nahr Umr and Majnoon fields along the Iraq-lran border is of about $435 \mathrm{~m}$, and in the Abu Amud field between Kut and Amara reach to $380 \mathrm{~m}$ [7]. The formation was deposited as rudist shoals and patch reefs over growing subtle structural highs developing in an otherwise relatively deeper shelf on which open marine sediments of the Rumaila Formation were deposited [7], The underlying Rumaila Formation consists predominantly of chalky and marly limestones. A conformable and gradational-junction with the Mishrif Formation are dark grey and greenish shales, alternating with grey, fine-grained marly limestones of the Khasib Formation [9]. 


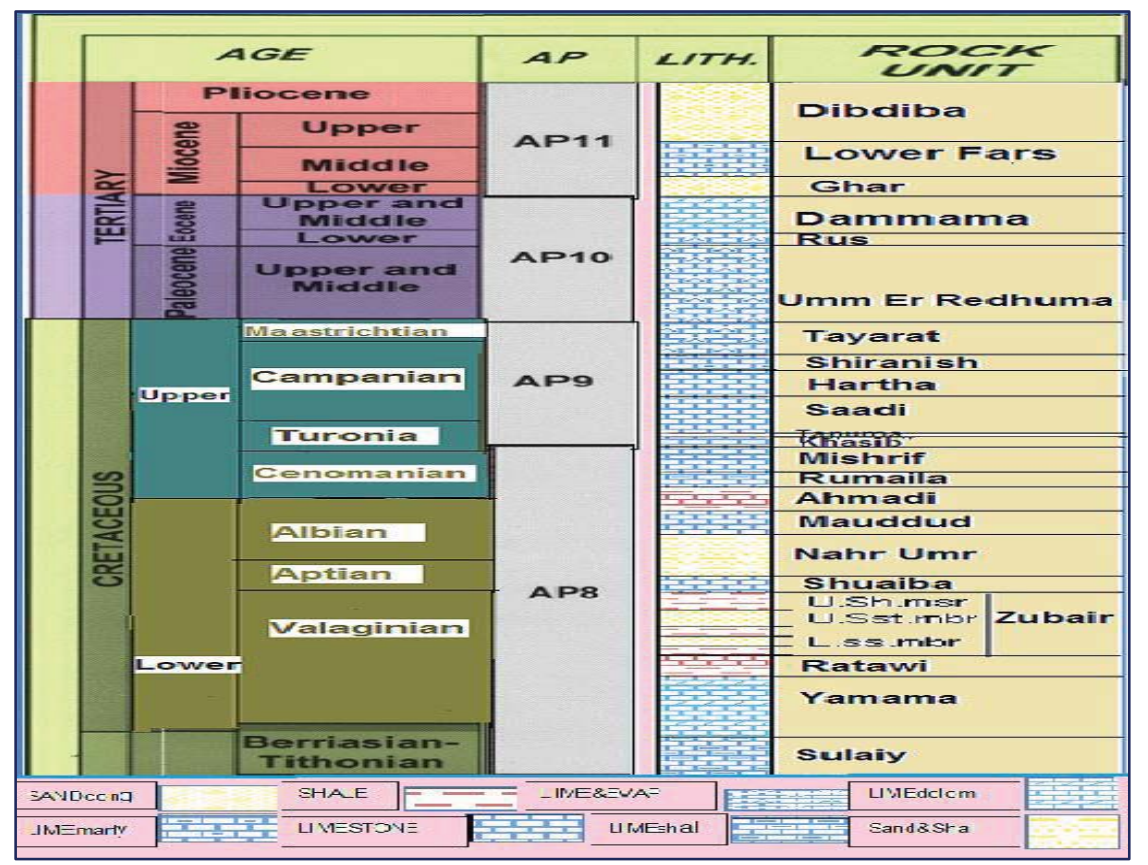

Fig. (2) Stratigraphy in southern Iraq ( $\mathrm{Zb}-49$ well).

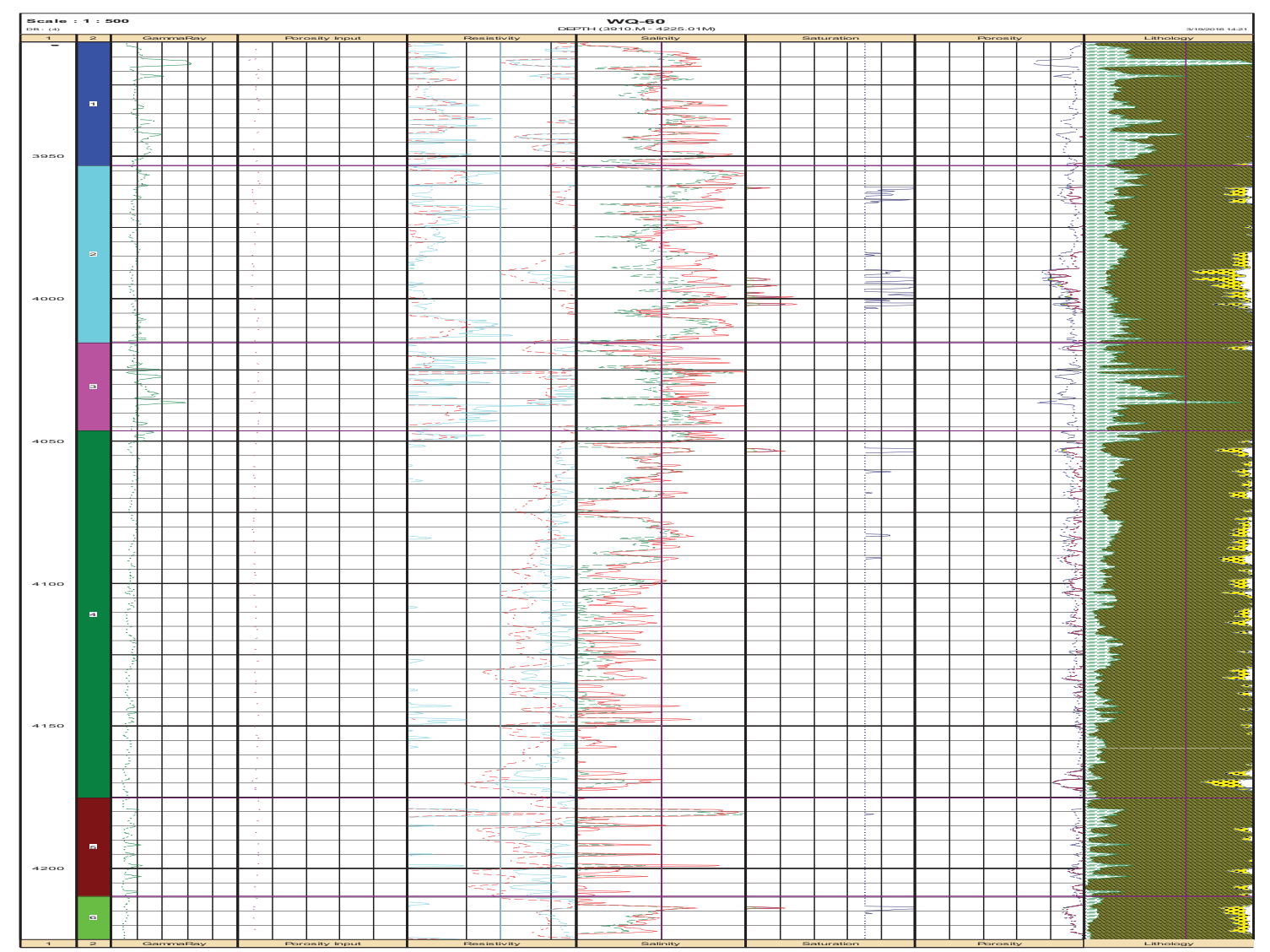

Fig (3) The zonation of Yamama formation in WQ-60. 


\section{Methodology:}

In this study, a set of equations were used to calculate the values of cementation factor and saturation exponent according to the type of rock, they are listed below along with their authors.

- Formula for clean Sand stone $m=\frac{\ln \left(\phi / a^{0.5}\right)}{\ln \emptyset} \quad$ (Wyllie, 1949) [21] and He (2005)[22] Adopted in the calculation of $m$ on the value of index $\sqrt{k / \varnothing}$ as following:

- $\mathrm{m}=2.36 \mathrm{e}^{-0.02 \varnothing} \quad$ for $\sqrt{\mathrm{k} / \varnothing} \quad \geq 0.92$

- $\mathrm{m}=0.03 \emptyset+1.38$ for $\sqrt{\mathrm{k} / \varnothing}<0.92$.

- Formula for carbonate $\mathrm{m}=2.2-0.035 /(\varnothing+0.042)$ (Borai, 1987) [23]

- Formula to calculated the cementation factor, $m$, in limestone and for different permeability values: (Focke and Munn, 1987) [24]

$$
\begin{aligned}
& \mathrm{m}=1.2+0.1286 \varnothing \quad \text { For } \mathrm{K}<0.1 \mathrm{md} \\
& \mathrm{m}=1.4+0.0857 \varnothing \quad \text { For } \mathrm{K}=0.1 \text { to } 1 \mathrm{md} \\
& \mathrm{m}=1.2+0.0829 \varnothing \quad \text { For } \mathrm{K}=1-100 \mathrm{md} \\
& \mathrm{m}=1.22+0.034 \varnothing \quad \text { For } \mathrm{K}>100 \mathrm{md} .
\end{aligned}
$$

The saturation exponent $(n)$ is calculated by plot the water saturation $(\mathrm{Sw})$ and the resistivity index $\left(I_{R}=R_{t} / R_{\circ}\right)$. This plot is usually yield a straight line with a slope equal to $n$. The calculated cementation factor and saturation exponent are used to calculate water saturation and the results were compared with that calculated using default values.

\section{Results and discussion}

When applying the equations for calculating $a$ and $m$ according to the rock type, the results confirmed that $a$ is equal to 2.5 in the Zubair formation, while it is equal to 2.21 in the Nahr Umar Formation, and 0.5 and 2 in the Mishrif and Yamama formations, respectively, Figure (4) and Table (1 2,3 and 4). Equations of Wyllie and He were used to calculate the $m$ coefficient of sandstone formations, Zubair and Nahr Umar. The new values of $m \& a$ were used to calculate water saturation, and the new results plotted with 
calculated water saturation values using default values. The correlation factor between the values of water saturation calculated by He equation and the calculated water saturation using laboratory-calculated are 0.78 and 0.85 for the Zubair and Nahr Umar formations, respectively Figure (5).

The coefficient of correlation between the values of water saturation using $m$ that calculated by Wyllie equation and the laboratory-calculated water saturation are 0.93 and 0.89 for Zubair and Nahr Umar formations. Respectively, Figure (5). Based on the above results it is clear that the Wyllie equation for calculating the $m$ coefficient of sandstone formations is better than the He equation, Figure (6).

The Borai and Fock equations were used to calculate the $m$ coefficient of carbonate formations, the Yamama and Mishrif formations, and the new values of $m \& a$ were used instead of the default in Archi equation to calculate water saturation. The new results were plotted with calculated water saturation values. Results show that values of coefficient of correlation between the values of water saturation using $m$ calculated by Borai equation and the calculated water saturation equal to 0.94 and 0.44 for the Mishrif and Yamama formations respectively, Figure (5).

The coefficient of correlation between the values of water saturation using $m$ calculated by Fock equation and the calculated water saturation are 0.78 and 0.21 for the Mishrif and Yamama formations respectively, Figure (5). Based on the results above, it is clear that the Borai equation for calculating the coefficient of $m$ for carbonate formations is better than the Fock equation, Figure (6). 

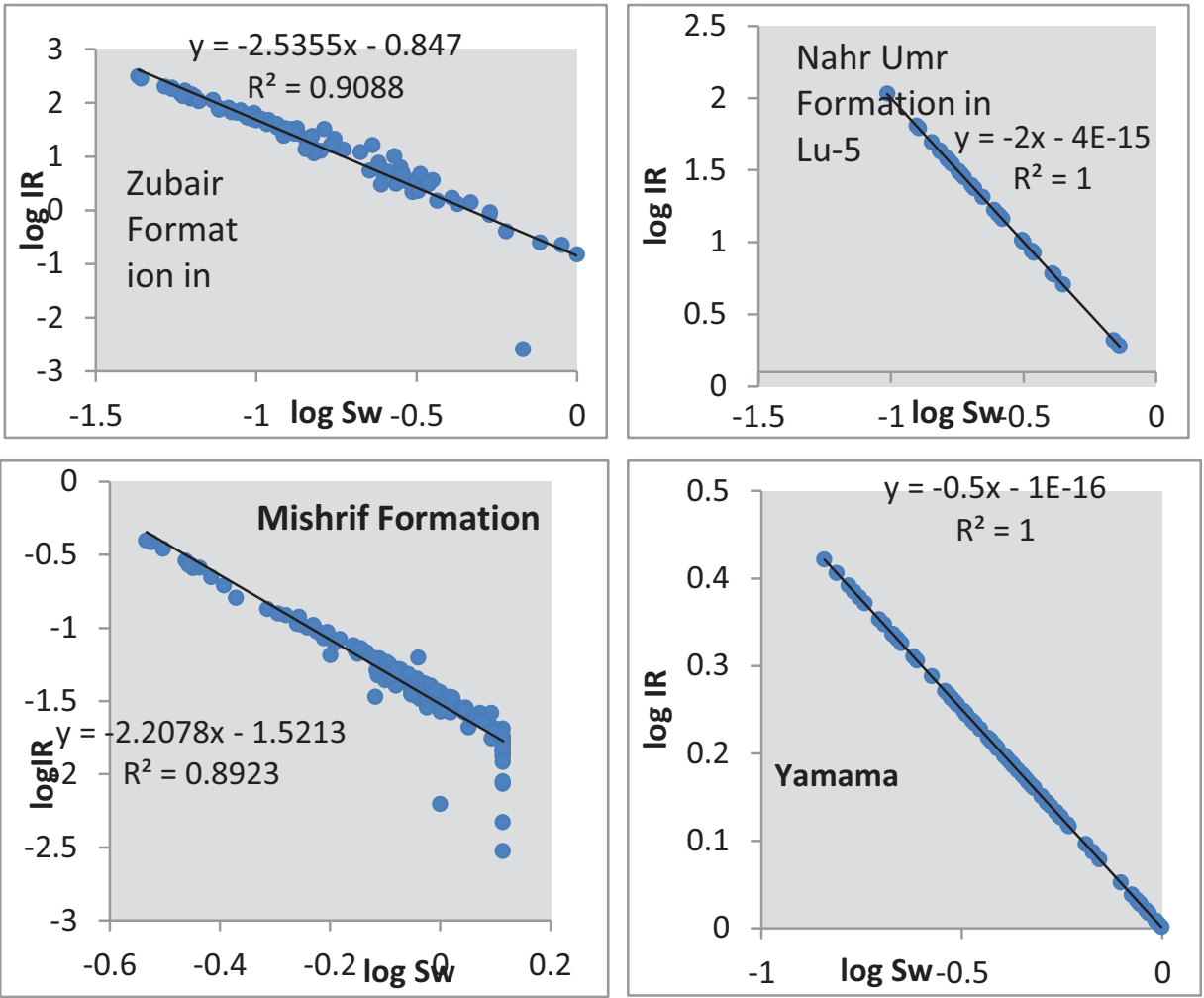

Fig. (4) Water saturation (Sw) Vs. the resistivity index IR for study area. 

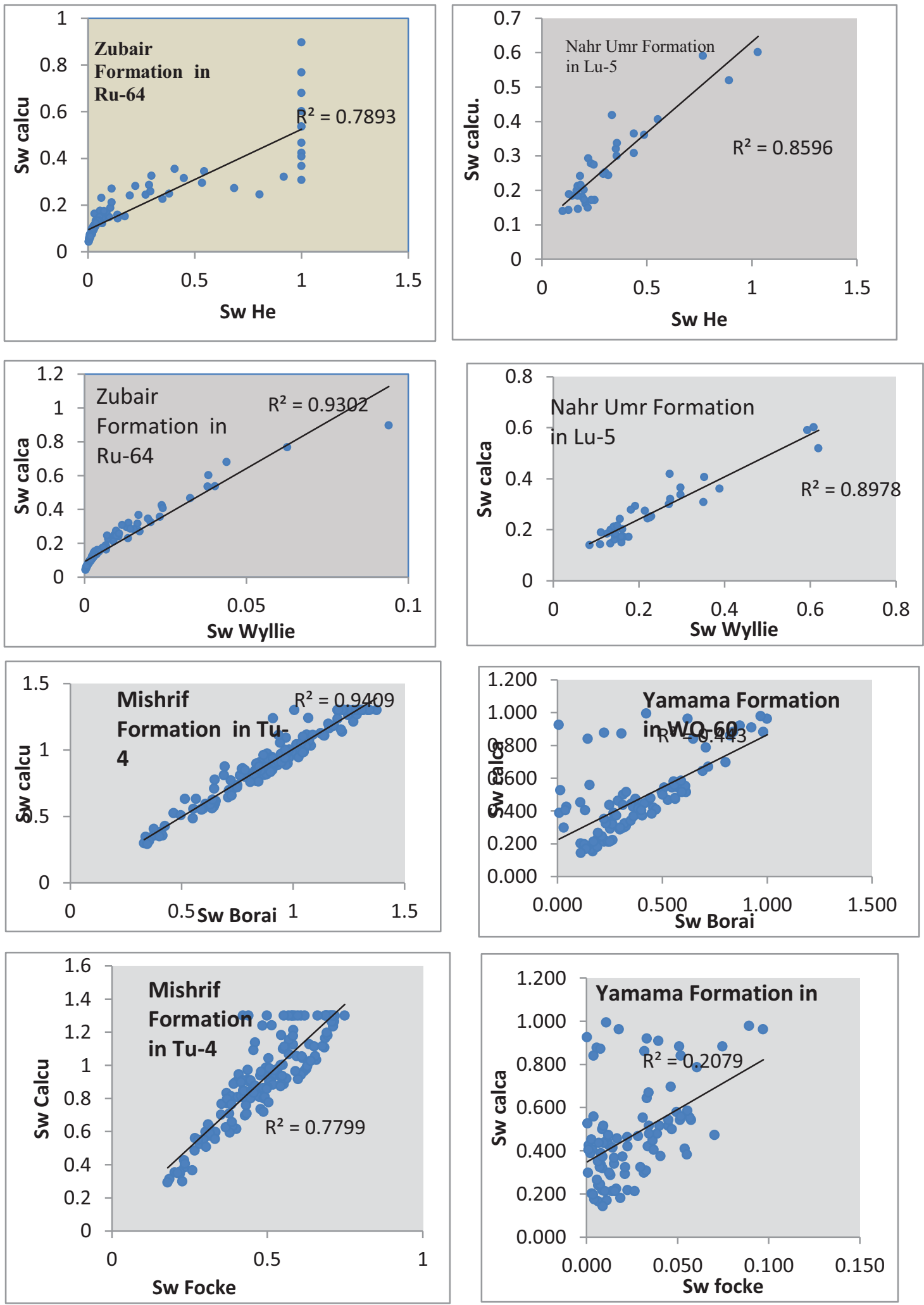

Fig. (5) Water saturation (Sw) using new values of a and mVs. water saturation calca. 

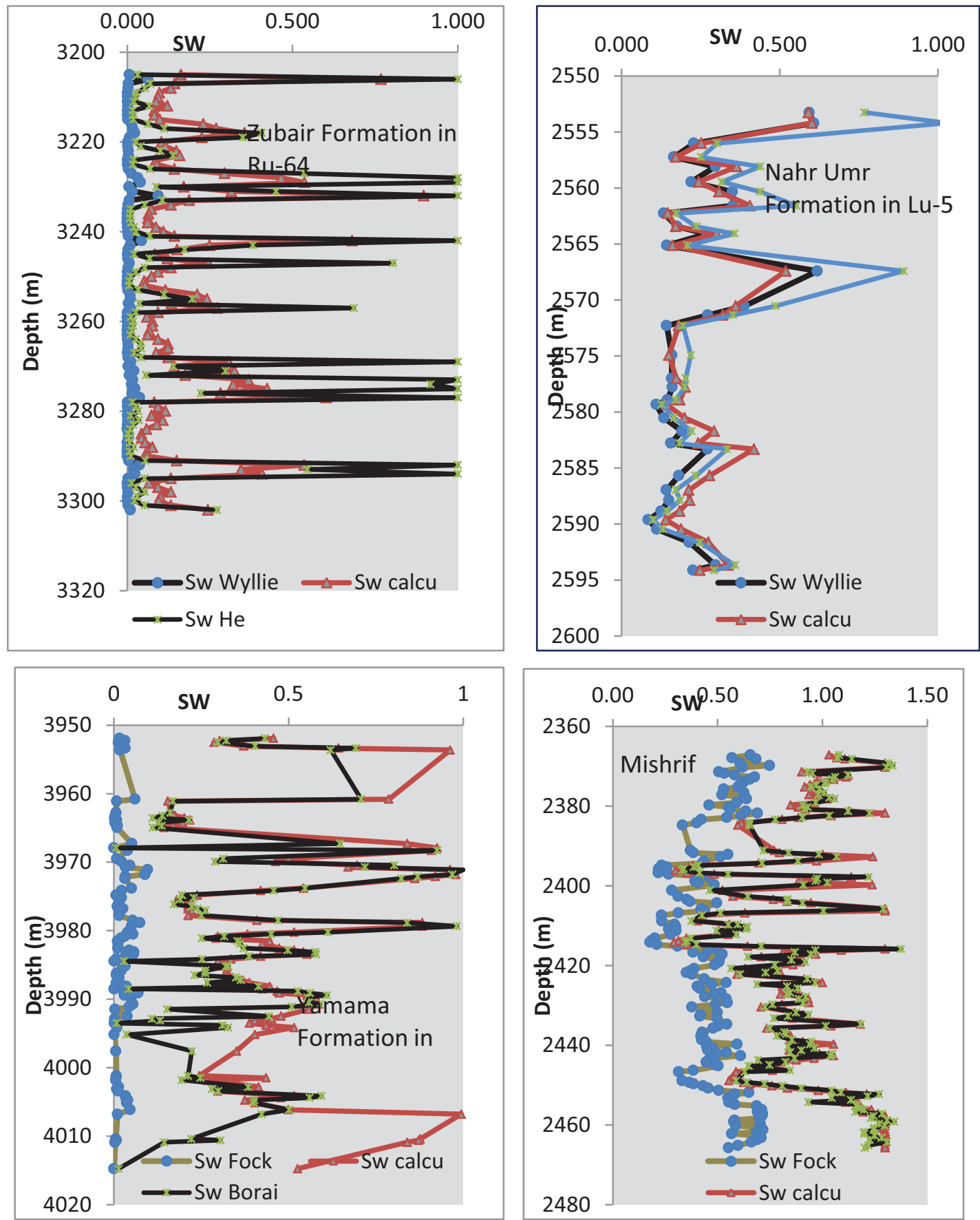

Fig. (6) Water saturation (Sw) vs. depth 


\section{Conclusions}

1) The Wyllie equation for calculating the $m$ coefficient of sandstone formations is better than the He equation.

2) The Borai equation for calculating the coefficient of $m$ for carbonate formations is better than the Fock equation.

3) The calculated values of $a$ and $m$ by empirical equations should be used instead of the default values in the calculation of water saturation. 


\section{$\underline{\text { References }}$}

1. Pirson, S. J. Oil reservoir engineering: McGraw-Hill.1977.

2. Carpenter, P. J., Ding, A. Z., Cheng, L. R., et al., 2009. Apparent Formation Factor for Leachate-Saturated Waste and Sediments: Examples from the USA and China. Journal of Earth Science, 20(3): 606-617, doi: 10.1007/s12583-009-0050-z.

3. Chen, L. Q., Zou, C. C., Wang, Z. H., et al., 2009. Logging Evaluation Method of Low Resistivity Reservoir-A Case Study of Well Block DX12 in Junggar Basin. Journal of Earth Science, 20(6): 1003-1011, doi: 10.1007/s12583-009-0086-0.

4. Archie GE (1942) The electrical resistivity log as an aid in determining some reservoir characteristics. Trans AIME 146:54-62.

5. Saeed Rafiee, Abdolnabi Hashemi, and Mohammad Shahi (2014): A New Cementation Factor Correlation in Carbonate Parts of Oil Fields in South-West Iran. Iranian Journal of Oil \& Gas Science and Technology, Vol. 3 (2014), No. 2, pp. 01-17.

6. Hamada G. M., Almajed A. A., Okasha T. M., Algathe A. A. (2013) Uncertainty analysis of Archie's parameters determination techniques in carbonate reservoirs. J Petrol Explor Prod Technol (2013) 3:1-10. DOI 10.1007/s13202-012-0042-x.

7. Jassim, S. Z., and Goff, J. C. (2006): Geology of Iraq. Published by Dolin, Prauge and Moravian Museum, Brno, $341 \mathrm{P}$.

8. Al-Siddiki, A.A.M., ( 1978): The geology and the hydrocarbon prospects of the Ratawi, Yamama and Sulaiy Formations in south-eastern Iraq subsurface section. Unpublished Report, Southetn Petroleum Organisation, pp.28.

9. Bellen, R. C. Van, Dunnington, H.V., Wetzel, R. and Morton, D.(1959) Lexique stratigraphique Internal Asie. Iraq. Intern. Geol .Conger. Comm. Stratigr, 3, Fasc. 10 a, 333 P.

10. Buday, T., (1980): The Regional Geology of 1raq. 1: Stratigraphy and Palaeogeography. 1n: Directorate General for Geological Survey and Mineral Investigations, State Organisation for Minerals Library, Baghdad, Iraq, Dar-AlKutir publishing House, Baghdad, pp.445.

11. Al-Sayab, A., (1989): Geology of petroleum, 472 pp. (University of Baghdad press, Baghdad.

12. Owen, R.M.S. and Nasr, S.N., (1958): Stratigraphy of the Kuwait Basrah area. In: 
Weeks, L. G. (Ed), Habitat of Oil. AAPG, Tulsa, pp.1252-1278.

13. Ali, T.S. 1985. First study round assemblage Osteichthyes in Khor Al-Zubair. M.Sc. thesis, College of Science, University of Basrah, 108pp (In Arabic).

14. Zeigler, M, A., 2001. Late Permian to Holocene Paleofacies Evolution of the Arabian Plate and its Hydrocarbon Occurrences-GeoArabia,6, 448-804.

15. Al-Ameri,T. K., and Batten,D. J.(1997): Palynomorph and Palynofacies indication of age, depositional environment and Source Potential for hydrocarbons lower Cretaceous, Zubair Formation, Southern Iraq. Cretaceous Research (1997), 18, P. 789-797.

16. Ibrahim, M.W., (1983): Petroleum geology of southern Iraq. AAPG Bull., 67 (1), 97-130.

17. Alsharhan, A.S., (1994): Albian clastics in the western Arabian Gulf region: asedimentological and petroleum-geological interpretation. Journal of Petroleum geology; V.17. pp 219-300.

18. Al-Ani, A.A, (1975): The geology and structure of Buzurgan Field, southeast Iraq. 9th Arab Petroleum Congress, paper 122 (B-3).

19. Al-Naqib, K.M., (1967): Geology of the Arabian peninsula, south-western Itaq. United States Geological Suruey, Professional Paper, 560 G, 54.

20. Dunnington, H.V., 1967.Stratigraphical distribution of oilfields in the Iraq-IranArabia Basin. Journ.Inst. Petrol.,53(520),129- 161.

21. Wyllie, M.R.J., and Rose, W.D.: A Note on the Theoretical Description of Wetting Liquid relative Permeability Data, Trans. AIME, Vol. 186, Notes, 1949.

22. He, Y. D., 2005. Analysis of Conductive Characteristic and Study of Evaluation Methods of Low Porosity and Permeability Reservoirs: [Dissertation]. China University of Petroleum, Beijing (in Chinese with English Abstract).

23. Borai A.M., A New Correlation for the Cementation Factor in Low-Porosity Carbonates, SPE Formation Evaluation. December 1987.

24. Focke J.W. and Munn M., Cementation Exponents in Middle East Carbonate Reservoir, SPE 13735, Formation Evalimdon, Jun.1987. 


\section{$\underline{\text { Nomenclature }}$}

Ro resistivity of fully water-saturated rock $(\Omega . \mathrm{m})$

$R \mathrm{t} \quad$ resistivity of the partly water-saturated rock $(\Omega . \mathrm{m})$

$R \mathrm{~W} \quad$ resistivity of water $(\Omega . \mathrm{m})$

$F \quad$ formation factor

Ir Resistivity index

$\phi \quad$ Porosity

m cementation factor

Sw water saturation

$n \quad$ saturation exponent.

K Permeability (md) 


\section{$\underline{\text { Appendix }}$}

Table(1) Results of Zubair Formation in Ru-64

\begin{tabular}{|c|c|c|c|c|c|c|c|}
\hline \multirow[t]{2}{*}{ Porosity } & \multirow{2}{*}{$\begin{array}{l}\text { Permeability } \\
\text { (md) }\end{array}$} & \multicolumn{2}{|c|}{$\begin{array}{c}\text { Value of m } \\
\text { calculated } \\
\text { according to }\end{array}$} & \multicolumn{3}{|c|}{$\begin{array}{c}\text { Value of water saturation } \\
\text { according to }\end{array}$} & \multirow[t]{2}{*}{ IR } \\
\hline & & $\begin{array}{l}\text { Wyllie } \\
\text { (1949) }\end{array}$ & $\begin{array}{c}\mathrm{He} \\
(2005)\end{array}$ & sw he & $\begin{array}{c}\text { Sw } \\
\text { calculated }\end{array}$ & sw wyllie & \\
\hline 0.158 & 105 & 1.169193 & 2.353 & 0.032 & 0.163 & 0.007 & 32.313 \\
\hline 0.188 & 354 & 1.053978 & 2.351 & 1.000 & 0.768 & 0.063 & 0.249 \\
\hline 0.197 & 463 & 1.049757 & 2.351 & 0.070 & 0.143 & 0.004 & 21.127 \\
\hline 0.199 & 498 & 1.087831 & 2.351 & 0.053 & 0.133 & 0.003 & 26.709 \\
\hline 0.224 & 556 & 1.092984 & 2.349 & 0.029 & 0.097 & 0.002 & 49.411 \\
\hline 0.243 & 1268 & 1.092984 & 2.349 & 0.027 & 0.094 & 0.002 & 53.418 \\
\hline 0.244 & 1760 & 1.092984 & 2.349 & 0.021 & 0.087 & 0.001 & 65.889 \\
\hline 0.255 & 1573 & 1.098137 & 2.348 & 0.067 & 0.122 & 0.002 & 24.164 \\
\hline 0.046 & 1.5 & 1.077583 & 2.358 & 0.017 & 0.082 & 0.001 & 79.813 \\
\hline 0.122 & 5.3 & 1.103371 & 2.354 & 0.017 & 0.082 & 0.001 & 79.813 \\
\hline 0.2 & 391 & 1.103371 & 2.351 & 0.019 & 0.099 & 0.002 & 64.794 \\
\hline 0.221 & 1154 & 1.119482 & 2.350 & 0.064 & 0.230 & 0.013 & 16.156 \\
\hline 0.186 & 443 & 1.169193 & 2.351 & 0.112 & 0.270 & 0.017 & 10.063 \\
\hline 0.167 & 205 & 1.139187 & 2.352 & 0.407 & 0.355 & 0.023 & 3.582 \\
\hline 0.199 & 441 & 1.090449 & 2.351 & 0.350 & 0.226 & 0.007 & 5.387 \\
\hline 0.223 & 916 & 1.066387 & 2.349 & 0.027 & 0.104 & 0.002 & 49.883 \\
\hline 0.162 & 232 & 1.103371 & 2.352 & 0.041 & 0.116 & 0.003 & 34.721 \\
\hline 0.15 & 351 & 1.092984 & 2.353 & 0.101 & 0.149 & 0.004 & 16.311 \\
\hline 0.17 & 35 & 1.077583 & 2.352 & 0.139 & 0.159 & 0.004 & 12.602 \\
\hline 0.196 & 66 & 1.072112 & 2.351 & 0.021 & 0.087 & 0.001 & 65.889 \\
\hline 0.19 & 636 & 1.098137 & 2.351 & 0.018 & 0.089 & 0.002 & 71.184 \\
\hline 0.161 & 237 & 1.108606 & 2.352 & 0.070 & 0.143 & 0.004 & 21.391 \\
\hline 0.113 & 1.2 & 1.08809 & 2.355 & 0.536 & 0.295 & 0.013 & 3.417 \\
\hline 0.189 & 795 & 1.069335 & 2.351 & 1.000 & 0.466 & 0.033 & 1.367 \\
\hline 0.218 & 1164 & 1.069335 & 2.350 & 1.000 & 0.536 & 0.040 & 0.899 \\
\hline 0.247 & 2058 & 1.06431 & 2.348 & 0.089 & 0.171 & 0.006 & 16.025 \\
\hline 0.234 & 1585 & 1.092984 & 2.349 & 0.450 & 0.315 & 0.016 & 3.625 \\
\hline 0.196 & 661 & 1.077583 & 2.351 & 1.000 & 0.897 & 0.094 & 0.221 \\
\hline 0.231 & 1295 & 1.053904 & 2.349 & 0.106 & 0.187 & 0.007 & 13.354 \\
\hline 0.229 & 1125 & 1.092984 & 2.349 & 0.053 & 0.133 & 0.003 & 26.709 \\
\hline 0.206 & 497 & 1.092984 & 2.350 & 0.011 & 0.073 & 0.001 & 111.490 \\
\hline 0.217 & 335 & 1.113969 & 2.350 & 0.010 & 0.064 & 0.001 & 129.696 \\
\hline 0.018 & 40.2 & 1.103371 & 2.359 & 0.009 & 0.063 & 0.001 & 142.606 \\
\hline 0.108 & 27 & 1.108659 & 2.355 & 0.012 & 0.063 & 0.001 & 119.921 \\
\hline
\end{tabular}


Table (2) Nahr Umer Formation in Lu-5

\begin{tabular}{|c|c|c|c|c|c|c|c|}
\hline \multirow{2}{*}{ Porosity } & \multirow{2}{*}{$\begin{array}{c}\text { Permeability } \\
(\mathbf{m d})\end{array}$} & \multicolumn{2}{|c|}{$\begin{array}{c}\text { Value of m calculated } \\
\text { according to }\end{array}$} & \multicolumn{3}{|c|}{$\begin{array}{c}\text { Value of water saturation } \\
\text { according to }\end{array}$} & \multirow{2}{*}{ IR } \\
\cline { 3 - 7 } & & $\begin{array}{c}\text { Wyllie } \\
(\mathbf{1 9 4 9})\end{array}$ & He (2005) & Sw he & $\begin{array}{c}\text { Sw } \\
\text { calculated }\end{array}$ & sw wyllie & \\
\hline 4.500 & 0.200 & 1.054 & 1.515 & 0.768 & 0.591 & 0.594 & 2.085 \\
\hline 19.400 & 7.000 & 1.027 & 1.962 & 1.029 & 0.602 & 0.608 & 1.922 \\
\hline 18.500 & 355.000 & 1.028 & 1.630 & 0.302 & 0.252 & 0.229 & 14.444 \\
\hline 20.100 & 8.000 & 1.027 & 1.983 & 0.252 & 0.172 & 0.165 & 28.037 \\
\hline 14.600 & 2.000 & 1.030 & 1.818 & 0.439 & 0.365 & 0.297 & 8.412 \\
\hline 14.800 & 2.500 & 1.030 & 1.824 & 0.317 & 0.244 & 0.220 & 15.659 \\
\hline 22.900 & 629.000 & 1.026 & 1.493 & 0.439 & 0.308 & 0.351 & 6.065 \\
\hline 17.900 & 3.800 & 1.028 & 1.917 & 0.553 & 0.406 & 0.353 & 5.922 \\
\hline 18.800 & 213.000 & 1.028 & 1.620 & 0.173 & 0.146 & 0.134 & 43.040 \\
\hline 16.400 & 20.000 & 1.029 & 1.700 & 0.236 & 0.172 & 0.176 & 24.757 \\
\hline 19.000 & 123.000 & 1.028 & 1.614 & 0.357 & 0.300 & 0.270 & 10.268 \\
\hline 16.900 & 4.700 & 1.029 & 1.887 & 0.208 & 0.162 & 0.143 & 37.410 \\
\hline 16.200 & 50.000 & 1.029 & 1.707 & 0.892 & 0.519 & 0.619 & 1.886 \\
\hline 4.500 & 3.100 & 1.054 & 1.515 & 0.487 & 0.361 & 0.388 & 5.057 \\
\hline 20.700 & 265.000 & 1.027 & 1.560 & 0.353 & 0.321 & 0.273 & 10.008 \\
\hline 15.700 & 90.000 & 1.030 & 1.724 & 0.194 & 0.181 & 0.143 & 37.494 \\
\hline 13.000 & 4.800 & 1.032 & 1.770 & 0.219 & 0.150 & 0.159 & 30.381 \\
\hline 19.800 & 462.000 & 1.027 & 1.588 & 0.203 & 0.173 & 0.159 & 30.423 \\
\hline 22.300 & 375.000 & 1.026 & 1.511 & 0.200 & 0.202 & 0.161 & 29.351 \\
\hline
\end{tabular}


Table (3) Mishrif Formation of Tu-4

\begin{tabular}{|c|c|c|c|c|c|c|c|c|}
\hline \multirow[b]{2}{*}{ Porosity } & \multirow[b]{2}{*}{$\begin{array}{l}\text { Permeabilit } \\
\text { y (md) }\end{array}$} & \multicolumn{3}{|c|}{$\begin{array}{l}\text { Value of } m \text { calculated } \\
\text { according to }\end{array}$} & \multicolumn{3}{|c|}{$\begin{array}{c}\text { Value of water saturation according } \\
\text { to }\end{array}$} & \multirow[b]{2}{*}{ IR } \\
\hline & & $\begin{array}{c}\text { Focke } \\
\text { and } \\
\text { Munn } \\
, 1987\end{array}$ & $\begin{array}{l}\text { Borai } \\
, 1987\end{array}$ & $\begin{array}{l}\text { Masoud, } \\
2008\end{array}$ & $\begin{array}{c}\text { Focke and } \\
\text { Munn } \\
1987\end{array}$ & Borai,1987 & $\begin{array}{l}\text { Sw } \\
\text { calcu. }\end{array}$ & \\
\hline 21.4 & 0.48 & 1.42 & $\begin{array}{l}2.0 \\
6\end{array}$ & 4.23 & 0.6575 & 1.081 & 1.03 & 2.98 \\
\hline 14.6 & 1.3 & 1.21 & $\begin{array}{l}2.0 \\
1\end{array}$ & 4.85 & 0.5693 & 1.073 & 1.07 & 2.63 \\
\hline 19.2 & 0.46 & 1.42 & $\begin{array}{l}2.0 \\
5\end{array}$ & 4.39 & 0.6843 & 1.141 & 1.11 & 3.22 \\
\hline 17.8 & 6.9 & 1.21 & $\begin{array}{l}2.0 \\
4\end{array}$ & 4.51 & 0.6086 & 1.316 & 1.30 & 3.30 \\
\hline 20.6 & 0.91 & 1.42 & $\begin{array}{l}2.0 \\
6\end{array}$ & 4.28 & 0.7494 & 1.336 & 1.30 & 3.68 \\
\hline 16.9 & 1 & 1.21 & $\begin{array}{l}2.0 \\
3\end{array}$ & 4.59 & 0.6203 & 1.307 & 1.30 & 3.00 \\
\hline 16 & 1 & 1.21 & $\begin{array}{l}2.0 \\
3\end{array}$ & 4.69 & 0.5069 & 0.93 & 0.90 & 2.41 \\
\hline 10.7 & 0.08 & 1.21 & $\begin{array}{l}1.9 \\
7\end{array}$ & 5.52 & 0.5329 & 0.953 & 0.98 & 2.51 \\
\hline 14.5 & 0.08 & 1.22 & $\begin{array}{l}2.0 \\
1\end{array}$ & 4.87 & 0.5833 & 1.124 & 1.13 & 2.74 \\
\hline 10 & 0.26 & 1.41 & $\begin{array}{l}1.9 \\
5\end{array}$ & 5.69 & 0.6782 & 1.062 & 1.12 & 3.15 \\
\hline 13.2 & 0.24 & 1.41 & $\begin{array}{l}2.0 \\
0\end{array}$ & 5.05 & 0.6548 & 1.049 & 1.06 & 3.04 \\
\hline 19.2 & 0.21 & 1.42 & $\begin{array}{l}2.0 \\
5\end{array}$ & 4.39 & 0.6256 & 1.017 & 0.98 & 2.91 \\
\hline 20.9 & 0.74 & 1.42 & $\begin{array}{l}2.0 \\
6\end{array}$ & 4.26 & 0.6187 & 1.013 & 0.96 & 2.87 \\
\hline 16.9 & 0.38 & 1.41 & $\begin{array}{l}2.0 \\
3\end{array}$ & 4.59 & 0.6087 & 0.972 & 0.94 & 2.82 \\
\hline 16.8 & 0.38 & 1.41 & $\begin{array}{l}2.0 \\
3\end{array}$ & 4.60 & 0.5993 & 0.948 & 0.92 & 2.72 \\
\hline 16.2 & 1 & 1.21 & $\begin{array}{l}2.0 \\
3\end{array}$ & 4.66 & 0.5302 & 0.987 & 0.96 & 2.42 \\
\hline 16.5 & 0.26 & 1.41 & $\begin{array}{l}2.0 \\
3\end{array}$ & 4.63 & 0.6267 & 1.009 & 0.98 & 2.88 \\
\hline 19.7 & 10 & 1.22 & $\begin{array}{l}2.0 \\
5\end{array}$ & 4.35 & 0.5225 & 0.982 & 0.94 & 2.42 \\
\hline 19.1 & 0.91 & 1.42 & $\begin{array}{l}2.0 \\
5\end{array}$ & 4.39 & 0.6289 & 1.035 & 0.99 & 2.94 \\
\hline
\end{tabular}


Table (4) Results of Yamama Formation in WQ-60

\begin{tabular}{|c|c|c|c|c|c|c|c|c|}
\hline \multirow[b]{2}{*}{ Porosity } & \multirow[b]{2}{*}{$\begin{array}{c}\text { Permeability } \\
\text { (md) }\end{array}$} & \multicolumn{3}{|c|}{$\begin{array}{l}\text { Value of } \mathbf{m} \text { calculated } \\
\text { according to }\end{array}$} & \multicolumn{3}{|c|}{$\begin{array}{c}\text { Value of water saturation } \\
\text { according to }\end{array}$} & \multirow[b]{2}{*}{ IR } \\
\hline & & $\begin{array}{c}\text { Focke } \\
\text { and } \\
\text { Munn } \\
, 1987\end{array}$ & $\begin{array}{r}\text { Borai } \\
, 1987\end{array}$ & $\begin{array}{c}\text { Masoud } \\
\text {,2008 }\end{array}$ & $\begin{array}{c}\text { Focke } \\
\text { and } \\
\text { Munn } \\
, 1987\end{array}$ & $\begin{array}{c}\text { Borai, } \\
1987\end{array}$ & $\begin{array}{c}\text { Sw } \\
\text { calcu. }\end{array}$ & \\
\hline 0.122 & 0.04 & 1.22 & 1.99 & 5.22 & 0.017 & 0.432 & 0.457 & 1.48 \\
\hline 0.148 & 0.22 & 1.41 & 2.02 & 4.83 & 0.032 & 0.322 & 0.303 & 1.82 \\
\hline 0.142 & 5.5 & 1.21 & 2.01 & 4.91 & 0.013 & 0.298 & 0.287 & 1.87 \\
\hline 0.155 & 1 & 1.21 & 2.02 & 4.74 & 0.020 & 0.405 & 0.372 & 1.64 \\
\hline 0.152 & 2.2 & 1.21 & 2.02 & 4.78 & 0.033 & 0.693 & 0.644 & 1.25 \\
\hline 0.08 & 0.04 & 1.21 & 1.91 & 6.33 & 0.018 & 0.621 & 0.963 & 1.02 \\
\hline 0.114 & 10 & 1.41 & 1.98 & 5.37 & 0.061 & 0.708 & 0.787 & 1.13 \\
\hline 0.158 & 3 & 1.21 & 2.03 & 4.71 & 0.008 & 0.169 & 0.154 & 2.55 \\
\hline 0.129 & 3.3 & 1.21 & 2.00 & 5.10 & 0.007 & 0.162 & 0.165 & 2.46 \\
\hline 0.098 & 2.5 & 1.21 & 1.95 & 5.74 & 0.004 & 0.139 & 0.176 & 2.39 \\
\hline 0.07 & 1.6 & 1.21 & 1.89 & 6.79 & 0.003 & 0.111 & 0.202 & 2.22 \\
\hline 0.13 & 10 & 1.21 & 2.00 & 5.08 & 0.009 & 0.215 & 0.218 & 2.14 \\
\hline 0.081 & 0.07 & 1.21 & 1.92 & 6.29 & 0.004 & 0.129 & 0.197 & 2.25 \\
\hline 0.1 & 0.32 & 1.41 & 1.95 & 5.69 & 0.011 & 0.137 & 0.170 & 2.42 \\
\hline 0.096 & 0.19 & 1.41 & 1.95 & 5.80 & 0.009 & 0.112 & 0.144 & 2.64 \\
\hline 0.095 & 0.15 & 1.41 & 1.94 & 5.82 & 0.052 & 0.647 & 0.840 & 1.09 \\
\hline 0.0076 & 0.03 & 1.20 & 1.49 & -32.93 & 0.000 & 0.007 & 0.926 & 1.04 \\
\hline 0.137 & 4.7 & 1.21 & 2.00 & 4.98 & 0.040 & 0.926 & 0.910 & 1.05 \\
\hline 0.078 & 8.5 & 1.21 & 1.91 & 6.41 & 0.009 & 0.313 & 0.500 & 1.41 \\
\hline 0.078 & 0.15 & 1.41 & 1.91 & 6.41 & 0.022 & 0.290 & 0.463 & 1.47 \\
\hline 0.178 & 6.6 & 1.21 & 2.04 & 4.51 & 0.046 & 0.802 & 0.697 & 1.20 \\
\hline 0.151 & 4.6 & 1.21 & 2.02 & 4.79 & 0.034 & 0.719 & 0.670 & 1.22 \\
\hline 0.142 & 0.28 & 1.41 & 2.01 & 4.91 & 0.097 & 1.000 & 0.963 & 1.02 \\
\hline
\end{tabular}

